\begin{abstract}
Tożsamość sportowa zawodników Olimpiad Specjalnych na przykładzie zawodników uprawiających pływanie - badanie pilotażowe

A - opracowanie koncepcji i założeń (preparing concepts)

B - opracowanie metod (formulating methods)

$\mathrm{C}$ - przeprowadzenie badań (conducting research)

D - opracowanie wyników (processing results)

E - interpretacja i wnioski (interpretation and conclusions)

F - redakcja ostatecznej wersji (editing the final version)

\section{Athletic identity of individuals participating in Special Olympics as exemplified by swimmers - pilot study}

\author{
Marta Wieczorek B,D,F, Wojciech Wiliński A,B,E, Aleksandra Sadziak A,C,F \\ Zakład Dydaktyki Szkolnej Kultury Fizycznej, Katedra Pedagogiki Kultury \\ Fizycznej, AWF we Wrocławiu, Physical Culture School Didactics Unit, \\ Department of Physical Culture Education, University of Physical Education \\ in Wroclaw
}

\section{Streszczenie}

Wstęp: Olimpiady Specjalne to stowarzyszenie, którego główną działalnością jest organizowanie treningów i zawodów sportowych dla osób z niepełnosprawnością intelektualną. U każdej z tych osób, występuje określona identyfikacja z uprawianą dyscypliną sportową - która zwana jest tożsamością sportową i stanowi ona przedmiot zainteresowań niniejszej pracy. Za cel poznawczy przyjęto rozpoznanie natężenia, którego miarę stanowi zgodność z tożsamością sportową wybranej grupy zawodników Olimpiad Specjalnych. Natomiast celem praktycznym jest wskazanie możliwości zastosowania zmodyfikowanego narzędzia badawczego w odniesieniu do osób z niepełnosprawnością intelektualną oraz upowszechnienie wiedzy na temat osób z niepełnosprawnością intelektualną.

Materiał $i$ metody: Badanie zostało przeprowadzone wśród uczestników VIII Dolnośląskiego Mitingu Pływackiego Olimpiad Specjalnych 2015 r. Metodą badawczą był sondaż diagnostyczny, techniką - wywiad, narzędziem - Zmodyfikowana Skala Pomiaru Tożsamości Sportowca wg Brewera.

Wyniki: Aspekty tożsamości sportowej ukazują, że większość zawodników Olimpiad Specjalnych uważa się za sportowca wyczynowego i zamierza nadal uczestniczyć w tym wariancie ruchu olimpijskiego. Najbliższe grono ich przyjaciół to również sportowcy wyczynowi. Dla połowy badanych osób sport jest najważniejszym elementem życia, natomiast porażka sportowa nie zmienia szczególnie ich samopoczucia.

Wnioski: U zawodników Olimpiad Specjalnych występuje wysoki poziom tożsamości sportowej, o czym świadczy m.in. znacząca pozycja sportu w ich życiu. Sport jest dla nich jednym z ważniejszych obszarów życia. Uczestnictwo w zawodach sportowych i treningach organizowanych przez Stowarzyszenie Olimpiad Specjalnych, odznacza się wyższą wartością dla osób z niepełnosprawnością intelektualną niż sama wygrana w rywalizacji sportowej.
\end{abstract}

Słowa kluczowe: $\quad$ Olimpiady Specjalne, niepełnosprawność intelektualna, tożsamość sportowa

\section{Abstract}

Introduction: Special Olympics is an association whose main objective is to organise training and sports competitions for individuals with intellectual disabilities. Each of 
these individuals manifests certain identification with the sport they do. It is called sports identity and is the subject of interest in this study. The cognitive aim of the study was to determine the intensity which is measured by the level of agreement with the sports identity in the selected group of athletes participating in Special Olympics. In turn, the practical purpose of the work was to indicate the possibilities of applying a modified research tool with regard to individuals with intellectual disabilities and to spread the knowledge about people with intellectual disabilities.

Material and methods: The study was conducted on the participants of the $8^{\text {th }}$ Lower Silesian Special Olympics Swimming Competition in 2015. A diagnostic poll was applied as a research method and an interview technique was used. Brewer's Modified Athletic Identity Measurement Scale was a research tool utilised in the study.

Results: Aspects of athletic identity revealed that the majority of Special Olympics participants believed that they were professional athletes and were planning to continue participating in this type of Olympic movement. Their closest friends were also professional athletes. For half of the study participants sport was the most significant part of their life, while a sports failure did not change their disposition.

Conclusions: The participants of Special Olympics manifest a high level of athletic identity, which is proven, inter alia, by the fact that sport is one of the most important parts of their lives. For individuals with intellectual disabilities, participation in sports competitions and training sessions organised by Special Olympics is more significant than winning in sports competition.

\section{Key words: $\quad$ Special Olympics, intellectual disability, sports identity}

\section{Wstęp}

Ruch Special Olympics (Olimpiad Specjalnych) powstał w myśl idei, by osoby $\mathrm{z}$ niepełnosprawnością intelektualną, mogły czerpać wiele korzyści, poprzez udział w sporcie, który jest dostosowany do ich możliwości. Dla zawodników Olimpiad Specjalnych, najważniejszym jest być dzielnym w swoim wysiłku, nawet gdy zwycięstwo nie zawsze jest możliwe do osiągnięcia. Ważniejszym jest samo zmaganie $\mathrm{z}$ własnymi słabościami oraz uczestnictwo w sportowej rywalizacji. Misją Olimpiad Specjalnych jest stworzenie warunków osobom z niepełnosprawnością intelektualną, do przeprowadzenia treningów sportowych, a następnie rywalizacji w zawodach sportowych [1].

Olimpiady Specjalne dedykowane są osobom z niepełnosprawnością intelektualną. Współcześnie niepełnosprawność intelektualną definiuje się w oparciu o zdolności osoby oraz jakość jej relacji z otoczeniem, rzadziej posługując się samym kryterium ilorazu inteligencji [2]. Takie spojrzenie na problem niepełnosprawności intelektualnej przedstawia AAIDD (Amerykańskie Stowarzyszenie Niepełnosprawności Intelektualnej i Rozwojowej), według którego niepełnosprawność intelektualna charakteryzuje się znacznymi ograniczeniami w funkcjonowaniu intelektualnym (czyli inteligencją, która dotyczy ogólnych zdolności umysłowych,

\section{Introduction}

Special Olympics movement was created so that individuals with intellectual disabilities could benefit from participation in sport adapted to their needs. For the participants of Special Olympic Games, the most significant aspect is to be brave in their efforts even if it is not possible for them to win. Fighting one's own weaknesses and participation in sports competition are more important. A mission of Special Olympics is to create conditions for individuals with intellectual disabilities to allow them to participate in sports training and sports competitions [1].

Special Olympics is dedicated to individuals with intellectual disabilities. Currently, intellectual disability is defined on the basis of the person's abilities and the quality of their relations with the surroundings rather than with the use of intelligence quotient criterion [2]. This is also the standpoint presented by the American Association on Intellectual and Developmental Disabilities (AAIDD), according to which, intellectual disability is characterised by significant limitations in intellectual functions (i.e. intelligence, which refers to such general mental abilities as reasoning, learning, solving problems) and at the same time in adaptive behaviours (conceptual, social and practical abilities and skills). It was concluded that intellectual disability manifests itself before the age of 18 [3]. Intellectual disability 
takich jak: rozumowanie, uczenie się, rozwiązywanie problemów) oraz równocześnie w zachowaniach adaptacyjnych (zestaw zdolności i umiejętności koncepcyjnych, społecznych i praktycznych). Stwierdzono, że niepełnosprawność intelektualna ujawnia się przed 18 r. ż. [3]. W podobny sposób pojęcie niepełnosprawności intelektualnej definiuje się w najnowszym wydaniu Diagnostycznego i Statystycznego Podręcznika Zaburzeń Umysłowych, DSM - V (Diagnostic and Statistical Manual - V) (2013) który podaje, że „[...]niepełnosprawność intelektualna to zaburzenie charakteryzujące się zarówno deficytem intelektualnym, jak i deficytem w funkcjonowaniu przystosowawczym z początkiem w okresie rozwojowym" [4].

U grupy osób z niepełnosprawnością intelektualną, podobnie jak w życiu każdego człowieka, sport może stać się dziedziną zainteresowań, która odgrywa znaczącą rolę. Dzieje się tak, kiedy to trenowanie wybranej dyscypliny sportowej, nadaje rytm dla codziennego funkcjonowania jednostki, a wszystkie sfery życia podporządkowują się tej aktywności. Osoby aktywne fizycznie zazwyczaj odznaczają się określonym poziomem identyfikacji ze społeczną rolą sportowca czy też z uprawianą dyscypliną sportową, które odpowiedzialne są za powstawanie tożsamości sportowej. Samo pojęcie ,tożsamość" do nauk społecznych wprowadził Erikson. Nie sformułował on jednak definicji tożsamości, ale dokonał rozdzielenia jej na dwa obszary, zwane poziomami. Pierwszy z nich, to poziom hipotetyczny, który jest efektem działania ego, czyli odnosi się wyraźniej do struktury wewnętrznej jednostki. Drugi poziom, zwany doświadczeniem, opiera się na osiągnięciu poczucia spójności i ciągłości, co wynika z integracji dotychczasowych doświadczeń [5]. Budowanie własnej tożsamości jest procesem wielce doniosłym i niełatwym. Zdaniem Tyszki, każdy dąży do tego, by zaistnieć w społeczeństwie, by być kimś wartościowym, zauważonym, a przy tym nie porzucać własnych przekonań. Umożliwić to może w pełni ukształtowana tożsamość jednostki, która stanowi jednocześnie warunek adekwatnej samooceny, a także poczucia, że jest się kimś ważnym i wyjątkowym, za czym idzie świadomość własnej osoby. Tożsamość to także atrybut szanowanego członka społeczności, która to opiera się na ogólnie akceptowanych wartościach w danej grupie [6]. Zdaniem Kozieleckiego procesy tożsamościowe inicjowane są na drodze w pełni świadomej, która doprowadza jednostkę do obrazu własnej is defined in a similar way in the current version of Diagnostic and Statistical Manual of Mental Disorders, $5^{\text {th }}$ Edition (DSM-5). According to the definition from the Manual, "intellectual disability is a disorder with onset in the developmental period that includes both intellectual and adaptive functioning deficits" [4].

Sport may become a significant field of interest among individuals with intellectual disabilities, just like in the life of any young individual. It happens when doing a selected sport provides a rhythm for everyday functioning of an individual and all the spheres of life are inferior to this activity. Physically active people usually manifest a particular level of identification with a social role of an athlete or with a sport they do, which is responsible for the development of athletic identity. The notion of identity was implemented in social sciences by Erikson. However, he did not formulate the definition of identity but divided it into two areas called levels. The first level is a hypothetical one which results from the activity of ego, i.e. it more clearly refers to an internal structure of an individual. The second level, called experience, is based on achieving the feeling of cohesion and continuity, which results from integrating previous experiences [5]. Building one's own identity is an important and difficult process. According to Tyszka, everyone wants to be recognised and valued in the society without abandoning their own convictions. It is possible when an individual has a fully shaped identity which also serves as a basis for adequate self-assessment and for the feeling of being important and unique, i.e. being self-aware. Identity is also an attribute of a respected member of a society based on generally accepted values in a given group [6]. According to Kozielecki, identity processes are initiated in a fully conscious manner that leads an individual to self-image. This image may be presented with a verbal message and can be updated in memory at any moment. The theory of Kozielecki indicates that identity is a multidimensional and complex personal judgement which is determined by self-awareness. A key role in developing identity and creating certain uniqueness of an individual is played by the so-called distinctive judgements. They refer to all the areas which distinguish an individual from the group, e.g. nationality [7].

There are two types of identity which may be referred to the aim of this study. The first type is personal (individual) identity understood as a system 
osoby. Obraz ten można przedstawić komunikatem werbalnym i w każdej chwili aktualizować w pamięci. Teoria Kozieleckiego podaje, że tożsamość jest sądem osobistym, który charakteryzuje się wielowymiarowością i złożonością, a uwarunkowany jest samoświadomością. By tożsamość miała szansę się rozwinąć i w efekcie powstała pewna odrębność jednostki, kluczową rolę muszą odegrać tzw. sądy dystynktywne. W ich zakresie mieszczą się wszystkie obszary, które stanowią wyróżnienie jednostki w grupie, czego przykładem jest narodowość człowieka [7].

Występują dwa rodzaje tożsamości, które bezpośrednio można odnieść do podjętego tematu pracy. Jest to tożsamość osobista (indywidualna) - rozumiana jako system wiedzy o sobie samym, o cechach charakterystycznych dla danej osoby, które jednocześnie najbardziej ją wyróżniają spośród innych (np. cechy fizyczne, upodobania, zdolności i umiejętności). Kolejna, to tożsamość społeczna rozumiana jako ten system wiedzy o sobie samym, który wiąże się z poczuciem przynależności do danej grupy społecznej (np. religia, przynależność do klubu sportowego, afiliacja polityczna) [8]. Dobrze rozwinięta tożsamość społeczna pomaga przystosować się jednostce do grupy, z którą się identyfikuje. Ten rodzaj tożsamości ułatwia relacje $\mathrm{z}$ otoczeniem, podnosi samoocenę, oraz usprawnia orientację w świecie społecznym. Proces kształtowania się tożsamości społecznej dokonuje się najczęściej samoistnie, dzięki zasłudze społeczności, która dostrzega osobiste talenty i zdolności jednostki. Możliwość rozwoju tożsamości sportowej, która stanowi przejaw integracji omówionej tożsamości osobistej wraz ze społeczną, umacnia się za pośrednictwem udziału w treningach i zawodach sportowych Olimpiad Specjalnych. Takie też stanowisko przedstawiła m.in. Krzywy, która łączy proces przygotowania zawodnika do mityngu pływackiego Olimpiad Specjalnych z podwyższeniem poziomu tożsamości sportowej [9] oraz Wiliński i wsp., którzy sugerują, że tożsamość sportowa jest konstruowana w oparciu o różny stopień natężenia aspektów roli sportowca. Nieodzowną rolę w tym procesie pełni Stowarzyszenie Olimpiad Specjalnych i działające na ich rzecz kluby sportowe, a także aktywność fizyczna w czasie wolnym. Ponadto wymienione formy aktywności fizycznej w ramach Olimpiad Specjalnych przyczynić się mogą do poszerzenia osobowości zawodników o aspekty związane $\mathrm{z}$ rywalizacją sportową. Wiliński i wsp. zauważają, że badana of knowledge about oneself or about one's own characteristics which distinguish the person from others (e.g. physical features, preferences, abilities and skills). The other type is social identity perceived as the system of knowledge about oneself which is connected with the feeling of belonging to a certain social group (e.g. religion, sports club membership, political affiliation) [8]. Well-developed social identity helps individuals to adjust to the group that they identify with. This type of identity makes relations with the surroundings easier, increases self-assessment and facilitates orientation in the social world. The process of shaping social identity usually takes place by itself owing to society members who notice personal talents and abilities of an individual. An opportunity to develop athletic identity which is a significant sign of integration of personal and social identity is enhanced due to the participation in training sessions and competitions of Special Olympics. Such a view is presented, inter alia, by Krzywy, who found a correlation between the process of preparing an athlete to the swimming competition of Special Olympics and an increased level of athletic identity [9]. Also, Wiliński et al. claimed that athletic identity is constructed based on various intensity levels of different aspects of an athlete's role. In this process, a significant role is played by Special Olympics Association, sports clubs which prepare for Special Olympics as well as free time physical activity. Moreover, the aforementioned forms of physical activity within Special Olympics may broaden athletes' personality by aspects connected with sports competition. Wilinski et al. noted that the group of athletes with moderate intellectual disability from Special Olympics Club in Wrocław identified themselves with the role of an athlete; however, a detailed analysis of the comments to the questions included in the Athletic Identity Measurement Scale (AIMS), which supplemented the quantitative characteristics of all the athletes, revealed certain differences between particular respondents [2].

The above information may serve as a basis for a more thorough analysis of athletic identity of Special Olympics participants. Does physical activity undertaken by individuals with intellectual disabilities only act as a certain element fulfilling their free time or does it play a leading role in the life of every Special Olympics participant? The cognitive aim of this study was to determine the intensity 
przez nich grupa zawodników z Klubu Olimpiad Specjalnych z Wrocławia z niepełnosprawnością intelektualną w stopniu umiarkowanym, utożsamia się z rolą sportowca, jednakże szczegółowa analiza komentarzy do pytań AIMS, uzupełniająca charakterystykę ilościową każdego zawodnika, wskazuje na pewne rozbieżności między poszczególnymi zawodnikami [2].

Powyższe informacje stanowić mogą podstawę do dokładniejszej analizy nad tożsamością sportową zawodników Olimpiad Specjalnych. Czy aktywność fizyczna, jaką podejmują osoby z niepełnosprawnością intelektualną, jest jedynie pewnym elementem wypełniającym czas w życiu tych osób, czy pełni ona wiodącą rolę w życiu każdego zawodnika Olimpiad Specjalnych? W niniejszej pracy został wyznaczony cel poznawczy, jakim jest rozpoznanie natężenia, którego miarę stanowi zgodność z tożsamością sportową, która charakteryzuje zawodników Olimpiad Specjalnych uprawiających pływanie. Natomiast za cel praktyczny przyjęto wskazanie możliwości zastosowania zmodyfikowanego narzędzia badawczego w odniesieniu do osób z niepełnosprawnością intelektualną oraz upowszechnienie wiedzy na temat osób z niepełnosprawnością intelektualną.

\section{Materiał i metody}

Badania, których wyniki zostały przedstawione w niniejszej pracy, zostały przeprowadzone wśród uczestników VIII Dolnośląskiego Mityngu Pływackiego Olimpiad Specjalnych w 2015r. na terenie pływalni Akademii Wychowania Fizycznego we Wrocławiu. Wywiad został przeprowadzony wśród 37 osób z niepełnosprawnością intelektualną w stopniu umiarkowanym, w przedziale wiekowym od 14 do 23 lat ( $M=18,5 ; S D=6,36)$. Staż zawodnika Olimpiad Specjalnych wynosił minimum 2 lata, co stanowiło jedno z kryteriów włączenia zawodnika do badania. Ponadto każdy z badanych komunikował się werbalnie, co umożliwiło przeprowadzenie wywiadu z każdym zawodnikiem indywidualnie. Uwzględniając przedstawione kryteria włączenia zawodników do grona badanych, procedura doboru sportowców była losowa i w efekcie spośród 123 zawodników, badanie objęło 37 osób. Zastosowaną metodą badawczą był sondaż diagnostyczny, techniką wywiad, a narzędziem zmodyfikowana Skala Pomiaru Tożsamości Sportowca wg Brawer'a, Van which is measured by the level of agreement with the sports identity characterising the selected group of swimmers participating in Special Olympics. In turn, the practical purpose of the work was to indicate the possibilities of applying a modified research tool with regard to individuals with intellectual disabilities and to spread the knowledge about people with intellectual disabilities.

\section{Material and methods}

The research was conducted on the participants of the $8^{\text {th }}$ Lower Silesian Special Olympics Swimming Competition in 2015 which took place at the swimming pool of the University of Physical Education in Wroclaw. An interview was conducted among 37 individuals aged 14 to $23(\mathrm{M}=18.5$; $\mathrm{SD}=6.36$ ) with moderate intellectual disability. Training experience of Special Olympics participants was minimum 2 years long, which was one of the inclusion criteria for the study. Moreover, each respondent communicated verbally, which made it possible to carry out interviews individually. Taking into account the aforementioned inclusion criteria, 37 athletes were randomly selected from the group of 123 individuals. A diagnostic poll was applied as a research method and an interview technique was used. The modified Athletic Identity Measurement Scale (AIMS) according to Brewer, van Raalte and Linder was a research tool utilised in the study. It assesses three dimensions, i.e. social identity (questions 1-2), exclusiveness (questions 3-5) and negative aspects (questions 6-7). Social identity refers to the strength of a respondent's identification with the role of an athlete, exclusiveness means the level of this identification, while negative factors are defined as negative emotional reactions resulting from giving up training and competition due to an injury or illness. The research with the use of AIMS has been carried out both among able-bodied athletes and individuals with disabilities, but also among persons who do practise any sport. The original AIMS includes 10 items; however, currently its shorter, 7-point version, in which 1 means "I fully disagree" and 7 "I fully agree", is applied in research. The reliability of AIMS with regard to able-bodied individuals according to Cronbach's $\alpha$ was 0.81-0.93, while with regard to individuals with disabilities it was 0.87-0.90 [10]. 
Raalte i Lindera (ang. Athletic Identity Measurement Scale; AIMS). Ocenia ona trzy wymiary: tożsamość społeczną (pytania $1-2$ ), wyłączność (pytania 3 - 5), czynniki negatywne (pytania $6-$ 7). Tożsamość społeczna dotyczy siły, z jaką dana osoba utożsamia się z rolą sportowca. Wyłączność to stopień do jakiego następuje identyfikacja $\mathrm{z}$ rolą sportowca, Natomiast czynniki negatywne określane są jako negatywne reakcje emocjonalne, które są rezultatem zaprzestania treningów i współzawodnictwa $\mathrm{z}$ powodu urazu czy choroby. Badania prowadzone z użyciem AIMS były wykonywane zarówno wśród sportowców pełnosprawnych jak i niepełnosprawnych a także osób, które nie zajmują się sportem. Oryginalna skala AIMS obejmuje 10 punktów (stwierdzeń), natomiast aktualnie w badaniach najczęściej wykorzystuje się jej skróconą 7 - punktową wersję, w której 1 oznacza ,zdecydowanie nie zgadzam się", a 7 ,zdecydowanie zgadzam się". Rzetelność skali AIMS w odniesieniu do osób pełnosprawnych wyniosła $\alpha-$ nCronbacha od 0,81 do 0,93, a wśród osób niepełnosprawnych, skalę charakteryzowała rzetelność na poziomie $\alpha-$ Cronbacha od 0,87 do 0,90 [10].

Na potrzeby przeprowadzenia niniejszych badań dokonana została modyfikacja narzędzia badawczego. Wynikała ona z konieczności dostosowania narzędzia do możliwości intelektualnych badanych. Siedmiostopniowa skala została przekształcona na skalę skróconą, która obejmowała trzy typy piktogramów: twarz uśmiechnięta, smutna oraz neutralna, które kolejno oznaczały: „, zgadzam się”, „nie zgadzam się", ,jestem niezdecydowany".

Wcześniej modyfikacji skali AIMS dokonał m.in. Wiliński i wsp, którzy zmienili 7 - stopniową likertowską skalę na obrazkową - zrozumiałą dla osób z niepełnosprawnością intelektualną. Skala piktogramowa składała się z 7 - iu uproszczonych rysunków twarzy, wyrażających emocje od smutku przez obojętność do radości (od 1 zdecydowanie nie zgadzam się - schemat smutnej twarzy do 7 - zdecydowanie zgadzam się - schemat uśmiechniętej twarzy) [2].

Badania wśród zawodników Olimpiad Specjalnych uprawiających pływanie, zostały przeprowadzone, z każdym zawodnikiem indywidualnie. Zadaniem badanej osoby było wskazanie piktogramu, który w najlepszy sposób odzwierciedla pozytywny lub negatywny stosunek do stwierdzeń związanych z uczestnictwem w sporcie. Pojedyncze pytania analizowano z uwzględnieniem udziału procentowego
The research tool was modified for the needs of this study. It resulted from the necessity to adapt the tool to intellectual abilities of the respondents. Seven-grade scale was shortened to three types of pictograms, i.e. a smiling face, a sad face and a neutral face which meant "I agree", "I disagree" and "I am not certain", respectively.

In the past, AIMS was modified, inter alia, by Wiliński et al., who changed the 7-point Likert scale into pictograms which could be understood by individuals with intellectual disabilities. This pictogram scale included 7 simplified images of a face expressing emotions from sadness, through indifference to happiness (from 1 meaning "I fully disagree" depicted by a sad face to 7 meaning "I fully agree" depicted by a smiling face) [2].

The study on swimmers participating in Special Olympics was conducted with each respondent being examined individually. The task of the respondents was to indicate the pictogram which best reflected their positive or negative attitude to statements connected with participating in sport. Separate questions were analysed with regard to the percentage of particular variants of responses (not certain, yes, no) in the whole group.

In the statistical analysis, the fractions test was used to find statistical significance of differences between the responses "I agree" (YES) and "I do not agree" (NO).

\section{Results}

The fractions test regarding identification with the group of professional athletes (statement 1) revealed that the vast majority of the respondents (approximately $78 \%$ ) declared their identification with this group, contrary to $19 \%$ of the study participants who did not consider themselves athletes. In these declarations, statistically significant differences between the responses Yes and No at the level $p<0.001$ were noted.

Nearly $68 \%$ of the respondents wanted to devote themselves to sport in the future (statement 2), while approximately $8 \%$ of the study participants did not want to continue their sports career. In this case, statistically significant differences between responses Yes and No at the level $\mathrm{p}<0.001$ were also noted.

The majority of the respondents (nearly 65\%) claimed that their friends were also athletes (statement 3). Nearly one in four study participants 
poszczególnych wariantów odpowiedzi (niezdecydowany, tak, nie) dla całej grupy badanej.

Do analizy statystycznej wykorzystano test frakcji dla ustalenia istotności statystycznej między odpowiedziami ,zgadzam się” (TAK) a ,nie zgadzam się" (NIE).

\section{Wyniki}

Tab. 1. Tożsamość sportowa zawodników Olimpiad Specjalnych Tab. 1. Athletic identity of the participants of Special Olympics

\begin{tabular}{|c|c|c|c|}
\hline \multirow[b]{2}{*}{ Stwierdzenia/ Statements } & \multicolumn{3}{|c|}{ Odpowiedzi/ Responses } \\
\hline & $\begin{array}{c}\text { Niezdecydowany/ Not certain } \\
{[\%]}\end{array}$ & Tak/ Yes $[\%]$ & Nie/ No [\%] \\
\hline 1. Uważam siebie za sportowca wyczynowego./ I consider myself an athlete. & 2,7 & $78,4^{*}$ & 18,9 \\
\hline 2. Mam wiele celów związanych ze sportem./ I have many goals related to sport. & 24,3 & $67,6^{*}$ & 8,1 \\
\hline $\begin{array}{l}\text { 3. Większość moich przyjaciół to sportowcy wyczynowi. } \\
\text { / Most of my friends are athletes. }\end{array}$ & 10,8 & $64,9 *$ & 24,3 \\
\hline $\begin{array}{l}\text { 4. Sport jest najważniejszym elementem mojego życia./ } \\
\text { Sport is the most important part of my life. }\end{array}$ & 5,4 & $54,1 *$ & 29,7 \\
\hline $\begin{array}{l}\text { 5. Spędzam więcej czasu myśląc o sporcie niż czymkolwiek innym./ } \\
\text { I spend more time thinking about sport than anything else. }\end{array}$ & 19 & 40,5 & 40,5 \\
\hline $\begin{array}{l}\text { 6. Czuję się źle, gdy nie odnoszę sukcesów sportowych./ } \\
\text { I feel bad about myself when I do poorly in sport. }\end{array}$ & 13,6 & 37,8 & 48,6 \\
\hline $\begin{array}{l}\text { 7. Byłbym przygnębiony gdybym był chory lub uległ urazowi i nie mógł } \\
\text { uprawiać sportu./ I would be very depressed if I were injured and could not } \\
\text { compete in sport. }\end{array}$ & 8,2 & 45,9 & 45,9 \\
\hline
\end{tabular}

*istotność statystyczną różnic na poziomie $\mathrm{p}<0,001$ między odpowiedziami Tak i Nie oznaczono symbolem $(*)$ / statistical significance of differences between the responses Yes and No at the level $\mathrm{p}<0.001$ is marked with $(*)$.
Przeprowadzony test istotności frakcji, dotyczący przynależności do grona sportowców wyczynowych (stwierdzenie 1), wykazał, że zdecydowana większość badanych, ok $78 \%$ deklaruje swoją jedność $\mathrm{z}$ gronem sportowców w przeciwieństwie do niespełna 19\%, którzy wcale nie uważają się za sportowców wyczynowych. W deklaracjach tych, występują różnice istotne statystycznie między odpowiedzią tak i nie na poziomie $\mathrm{p}<0,001$.

Blisko $68 \%$ badanych chce związać swoją przyszłość ze sportem (stwierdzenie 2), natomiast ok. 8\% w przyszłości nie zamierza kontynuować kariery sportowca. Tu również występują różnice istotne statystycznie między odpowiedzią tak i nie na poziomie $\mathrm{p}<0,001$.

Wśród pytanych, większość, ponieważ prawie $65 \%$ twierdzi, że ich przyjaciele to również sportowcy (stwierdzenie 3). Niespełna jedna czwarta badanych jest przeciwnego zdania i twierdzi, że wśród sportowców nie mają oni przyjaciół. Tu także wystąpiły różnice istotne statystycznie między odpowiedzią tak i nie na poziomie $\mathbf{p}<0,001$. provided a different response claiming that they did not have any friends among athletes. In this case, statistically significant differences between responses Yes and No at the level $p<0.001$ were also noted.

Sport was the most important part of life (statement 4) for slightly over half of the study participants, while nearly $30 \%$ of them did not consider sport to be such a significant element of their life.
No statistically significant differences between responses Yes and No at the level $p<0.001$ were noted.

In the examined group, nearly $41 \%$ of the athletes devoted time to thinking about sport more often than anything else (statement 5) and the same number of the study participants provided an opposite response.

Negative emotions connected with the lack of sports successes (statement 6) accompanied nearly $38 \%$ of the respondents. However, over $48 \%$ of the study participants did not feel bad when doing poorly in sport.

Nearly $46 \%$ of the athletes claimed that they would be depressed if they were injured and could not compete in sport (statement 7) and, on the other hand, the same percentage of the subjects would not feel depressed if they could not participate in a selected sports activity. 
Sport jest najważniejszym elementem życia (stwierdzenie 4) dla nieco ponad połowy badanych, a niespełna $30 \%$ nie uważa sportu za tak istotny element swojego życia. Między odpowiedzią tak i nie wystąpiły różnice istotne statystycznie na poziomie $\mathrm{p}<0,001$.

Wśród badanej grupy zawodników, niecałe $41 \%$ poświęca czas na myślenie o sporcie częściej, niż o czymkolwiek innym (stwierdzenie 5) i taka sama grupa badanych jest zupełnie odmiennego zdania.

Negatywne emocje w związku z brakiem sukcesów sportowych (stwierdzenie 6) towarzyszą prawie $38 \%$ osobom. Natomiast ponad $48 \%$ wcale nie czuje się źle gdy ponosi porażkę.

Taka sama grupa, licząca blisko 46\%, twierdzi, że byłaby przygnębiona gdyby z powodu choroby nie mogła uprawiać sportu wyczynowego (stwierdzenie7) i przeciwnie - wcale tego przygnębienia by nie odczuła, gdyby nie mogła uczestniczyć w wybranej aktywności ruchowej.

\section{Dyskusja}

Przeprowadzone badania, ukazały jaki jest poziom tożsamości sportowej wybranej grupy zawodników Olimpiad Specjalnych. Uwaga badaczy, została skierowana na aspekt psycho - społeczny i jak podaje Cedro, jest to sfera, gdzie rola sportu zostaje sprowadzona do wewnętrznych przeżyć jednostki, jej potrzeb współzawodnictwa, ekspresji osobowości, rozładowania psychicznych napięć oraz względów hedonistycznych [11].

Podczas obserwacji grupy osób z niepełnosprawnością intelektualną, Lesiuk i Martyniuk, dostrzegły, że badana młodzież, bardzo chętnie uczestniczy w zajęciach sportowych, a przeżyciem pozostawiającym trwały ślad w ich psychice są zawody sportowe. Rywalizacja sportowa dla osób niepełnosprawnych intelektualnie jest walką ze swoimi słabościami, wadami - walką z samym sobą. Słowo „sport” nie należy kojarzyć jedynie z rekordami i medalami, lecz podporządkowany jest on także celom rewalidacji i sportowej rekreacji. Autorki powyższych obserwacji podczas pracy z uczniami biorącymi udział w rywalizacji sportowej Olimpiad Specjalnych, dostrzegły, że niepełnosprawni intelektualnie, czerpią radość przede wszystkim z możliwości wzięcia udziału w zmaganiach sportowych Olimpiad Specjalnych. Jest to dla nich i ich rodzin wielkie przeżycie. Potrafią cieszyć się z wygranej,

\section{Discussion}

The study revealed the level of athletic identity in the selected group of athletes participating in Special Olympics. The focus of this study was on a psycho-social aspect and according to Cedro, it is a sphere where the role of sport is reduced to internal experiences of individuals, their need for competition, expression of personality, relieving mental tensions and hedonistic aspects [11].

While observing a group of athletes with intellectual disabilities, Lesiuk and Martyniuk noted that the examined adolescents were eager to participate in sports classes while sports competitions were unforgettable experiences for them and a way of struggling with their own weaknesses and vices. The notion "sport" should not be associated only with records and medals but it is also aimed at revalidation and sports recreation. While working with pupils and students participating in sports competitions of Special Olympics, the authors of the above observations noted that individuals with intellectual disabilities took joy mainly in an opportunity to participate in Special Olympics. It was a huge experience for them and their families. They could take joy in winning but they also learnt to fail. Lesiuk and Martyniuk quoted one of the participants of Special Olympics: "The best part is that I can swim and compete to win. If I sometimes fail, I know that I have to practise to succeed. I like participating in the Olympics even when I fail" [12]. The analysis of the responses to the AIMS ('yes' versus 'no') showed that the players were not affected too much by their failures during competitions, and regardless of them, sport was one of the central areas of their personality.

Athletic identity was the subject of research, inter alia, by Tasiemski and Brewer, who examined patients after spinal cord injuries. The aim of their research was to assess whether athletic identity was stronger before or after the injury. The participants confirmed they were more engaged in sport after the injury than before. The obtained results indicated that the role of sport in the process of adapting to life after a spinal cord injury was invaluable. In turn, individuals who engaged in sport after the injury manifested a higher level of athletic identity than patients who did not take up any physical activity. According to Tasiemski, they also adapted better mentally and, therefore, participating in sport was so significant [13]. 
ale i uczą się przegrywać. Lesiuk i Martyniuk przytaczają zdanie, jednego z zawodników Olimpiad Specjalnych: „Najfajniejsze jest to, że mogę pływać i walczyć o to, aby wygrać. A jak mi czasami się nie udaje to wiem, że muszę ćwiczyć, żeby w końcu się udało. Lubię brać udział w olimpiadzie. Nawet jak nie wygrywam" [12]. Analiza odpowiedzi na pytania z AIMS (tak vs nie) pokazuje, że zawodnicy nie przeżywają nadmiernie porażek podczas zawodów, a sport bez względu na to należy do centralnych obszarów ich osobowości.

Tożsamość sportowców była przedmiotem badań między innymi Tasiemskiego i Brewera, które odbyły się z udziałem osób po urazie rdzenia kręgowego. Celem tych badań było sprawdzenie, czy tożsamość sportowa była większa przed czy po urazie rdzenia kręgowego. Uczestnicy wskazywali na większe zaangażowanie $\mathrm{w}$ sport po urazie niż przed. Uzyskane wyniki wskazują, iż rola sportu w procesie dostosowywania się do życia z urazem rdzenia jest nieoceniona. Natomiast osoby, które po urazie rdzenia kręgowego, stały się uczestnikami sportu, mogą charakteryzować się wyższym poziomem tożsamości sportowej niż osoby, które nie zaangażowały się w aktywność ruchową. Prezentują oni zwiększone psychologiczne dostosowanie, stąd zdaniem Tasiemskiego, uczestnictwo w sporcie jest tak istotne [13].

Porównując sportowców Olimpiad Specjalnych i wyniki uzyskane przez Tasiemskiego i Brewera, dostrzec można, że rodzaj niepełnosprawności wcale nie warunkuje natężenia tożsamości sportowej, lecz przypuszczalny indywidualny poziom zaangażowania w sport.

Kolejne badanie prowadzone przez Tasiemskiego i wsp. objęło grupę niewidomych kolarzy tandemowych i ich pełnosprawnych pilotów. Zespół badaczy, chciał się dowiedzieć, czy „silniejsze” zaangażowanie $\mathrm{w}$ rywalizację sportową modyfikuje poziom tożsamości sportowej. Niewidomi sportowcy posiadali niższy poziom tożsamości sportowej niż ich piloci. Porównanie dwóch typów osobowości sportowej (słabszej i silniejszej), które prezentować mogą niewidomi zawodnicy $\mathrm{i}$ ich piloci $\mathrm{z}$ tandemu kolarskiego, wskazuje, że występujący u nich rozwój tożsamości sportowej może przebiegać w oparciu o zupełnie inne przeżycia emocjonalne [14].

Wśród autorów, którzy podjęli zbliżoną tematykę badań, są także Harady i Sipestein. Podają oni, że osiągnięcia sportowe nie są najpopularniejszym rodzajem motywacji, który, deklarują zawodnicy
While comparing the results of Special Olympics participants with the results obtained by Tasiemski and Brewer, it can be noted that the type of disability does not affect the intensity of athletic identity, but it may affect a potential individual level of engagement in sport.

In another study, Tasiemski et al. examined a group of non-sighted tandem cyclists and their sighted pilots. The team of researchers wanted to determine whether "stronger" engagement in sports competition modified the level of sports identity. Blind athletes manifested a lower level of athletic identity than their pilots. The comparison of two types of sports personality (weaker and stronger one) noted in blind tandem cyclists and their sighted pilots revealed that their sports identities may develop on the basis of completely different emotional experiences [14].

Other authors who were working on similar issues include Harada and Siperstein. They concluded that sports achievements are not the most popular motivating factor declared by athletes participating in Special Olympics. It is by far less common than fun and pleasure connected with doing sports and an opportunity to make friends with other athletes [15].

Similar study conducted by Wiliński et al. indicated that the participants of Special Olympics identify themselves with the role of an athlete and on the basis of this, their sports personality is created. They also indicated certain limitations in their research resulting from adapting the research tool which had to be modified to meet the needs of individuals with intellectual disabilities. The analysis of results was based both on quantitative results and on summarised comments to the statements provided by all the respondents. This, according to the authors, referred to the level of athletic identity. Such a research procedure revealed, inter alia, that despite a disagreement between her interests and sports she was doing, one of the female athletes identified herself with the role of an athlete and achieved a very high result in AIMS. The research results obtained by Wiliński et al. leave room for discussion and suggest analysing potential implications for athletes with intellectual disabilities [2].

The results obtained in our research do not differ significantly from the ones presented in the study by Wiliński et al. The examined swimmers also manifested a high level of athletic identity (indicated by a higher percentage of the responses "yes" in the AIMS). Moreover, the tool was modified even more, i.e. the 
biorący udział w wydarzeniach sportowych Olimpiad Specjalnych. Zdecydowanie ustępują one zabawie i przyjemności związanej z uprawiania sportu oraz możliwości nawiązywania przyjaźni z innymi sportowcami [15].

Podobne badanie przeprowadzone przez Wilińskiego i wsp., ukazują, że zawodnicy Olimpiad Specjalnych identyfikują się z rolą sportowca i tworzą w oparciu o nią osobowość sportową. Wskazują również na pewne ograniczenia $\mathrm{w}$ przeprowadzeniu badań, wynikające $\mathrm{z}$ adaptacji narzędzia, które dla grupy osób z niepełnosprawnością intelektualną wymagało modyfikacji. Analiza wyników badań opierała się zarówno na ilościowych rezultatach jak i streszczonych komentarzach do twierdzeń każdego z badanych, co wspólnie w domniemaniu autorów dotyczy natężenia tożsamości sportowej. Takie postępowanie badawcze ukazało m.in., że jedna $\mathrm{z}$ zawodniczek, mimo niezgodności między zainteresowaniami, a uprawianymi dyscyplinami sportowymi, utożsamia się z rolą sportowca i osiąga bardzo wysoki wynik w AIMS. Wyniki badań uzyskane przez Wilińskiego i wsp. pozostawiają otwartą drogę do dyskusji i sugerują by w przyszłości rozważyć możliwe wynikające $\mathrm{z}$ nich implikacje dla sportowców $\mathrm{z}$ niepełnosprawnością intelektualną [2].

W nawiązaniu do wyników otrzymanych w niniejszej pracy, nie dostrzega się wyraźnych odstępstw od tych uzyskanych przez Wilińskiego i wsp. Badani zawodnicy uprawiający pływanie również odznaczają się wysokim poziomem tożsamości sportowej (na co wskazuje większy udział procentowy odpowiedzi „tak” na pytania AIMS). Prócz tego, modyfikacja narzędzia była jeszcze węższa, gdzie z 7 stopniowej Skali Likerta, ograniczono badanie jedynie do 3 wariantów odpowiedzi i zastąpione je odpowiednimi piktogramami, co stanowiło konieczność pomyślnego przeprowadzenia wywiadu $\mathrm{z}$ badaną grupą.

Badaniami na temat tożsamości sportowej zawodników Olimpiad Specjalnych na przykładzie zawodników uprawiających pływanie zajmowała się także Krzywy, studentka Akademii Wychowania Fizycznego we Wrocławiu. Zarówno metoda, jak i technika i narzędzie (Zmodyfikowana Skala Pomiaru Tożsamości Sportowca wg Brewera i wsp.) pokrywają się $\mathrm{z}$ badaniami przeprowadzonymi w niniejszej pracy. Badanie to miało miejsce podczas VII edycji Dolnośląskiego Mityngu Pływackiego Olimpiad Specjalnych w 2013 roku (edycja poprzedzająca mityng, podczas którego przeprowadzono 7-point Likert scale was limited to three variants of responses replaced with pictograms, which served as a basis for successful interviews with the respondents.

The research on athletic identity of swimmers participating in Special Olympics was also carried out by Krzywy, a student from the University of Physical Education in Wroclaw. The author applied the same method, technique and tool (the modified Athletic Identity Measurement Scale according to Brewer et al.) as the ones used in our study. The research was carried out during the $7^{\text {th }}$ Lower Silesian Special Olympics Swimming Competition in 2013 (the competition preceding the one during which our research was conducted). The comparison of results revealed certain discrepancies. For instance, in the research by Krzywy the majority (nearly 68\%) of the athletes felt bad when they did poorly, while in our research it was not such a significant element during competitions (it was declared by nearly $38 \%$ of the respondents). In 2013, sport was the most significant part of life for virtually all the swimmers; however, in our research it was the most important aspect for slightly more than half of the respondents. As far as the question regarding injuries is concerned, in 2013 all the respondents declared that they would be depressed if they were injured and could not compete in sport. However, in our research nearly $50 \%$ of the athletes would not feel depressed because of an injury [9].

\section{Conclusions}

1. The participants of Special Olympics manifest a high level of athletic identity. It is proven by a vital role of sport in the lives of the examined athletes. It is one of the most important parts of life among Special Olympics participants.

2. For individuals with intellectual disabilities, sport has more dimensions than only competition and winning medals. It is a way of developing not only a spiritual but also emotional sphere, socialising and making friends with other athletes. For athletes with intellectual disabilities, the participation in Special Olympics competition is more important than victory.

3. The applied modification of the research tool, i.e. the reduction to three possible answers expressed as pictograms, is an interesting proposition in the field of methodology of research adapted to the needs of individuals with intellectual disabilities. 
badania w niniejszej pracy). Po zestawieniu wyników, zauważono pewne rozbieżności, w tym dane, że większość zawodników (blisko 86\%) czuło się źle, gdy nie odnosiło sukcesów sportowych natomiast obecnie nie jest to tak ważny element w przebiegu zawodów sportowych - tak deklaruje blisko $38 \%$ badanych. W 2013 r. praktycznie dla wszystkich zawodników uprawiających pływanie,, sport był najważniejszym elementem życia, dziś jest nim dla nieco ponad połowy badanych osób z niepełnosprawnością. Inaczej jednak przypadku pytania o kontuzję, przy którym wszyscy badani z 2013 roku zadeklarowali, że gdyby z tego powodu musieliby zaprzestać udziału w zawodach sportowych, byliby przygnębieni. Co w porównaniu do rezultatów otrzymanych przez autorów niniejszej pracy, blisko $50 \%$ - wcale nie odczuwałoby przygnębienia $\mathrm{z}$ tego powodu [9].

\section{Wnioski}

1. U zawodników Olimpiad Specjalnych występuje wysoki poziom tożsamości sportowej. Świadczy o tym deklarowana mocna pozycja sportu w życiu badanej grupy. Jest on jednym z ważniejszych elementów życia zawodników Olimpiad Specjalnych.

2. Sport dla osób z niepełnosprawnością intelektualną ma znacznie większy wymiar niż ten, który powszechnie utożsamiany jest $\mathrm{z}$ rywalizacją i zdobywaniem medali. Jest on sposobem na rozwijanie nie tylko sfery ruchowej, ale także emocjonalnej, uspołecznienie oraz nawiązywanie przyjaźni z innymi zawodnikami. Dla osób z niepełnosprawnością intelektualną, ważniejsze jest samo uczestnictwo w mityngu Olimpiad Specjalnych niż wygrana.

3. Zastosowana modyfikacja narzędzia badawczego polegająca na redukcji do trzech możliwych odpowiedzi wyrażonych za pomocą piktogramów, stanowi ciekawą propozycję w zakresie metodologii badań dostosowanych do możliwości osób z niepełnosprawnością intelektualną.-

Ograniczenia, wynikające z braku uwzględnienia podziału badanych osób ze względu na płeć, pozwalają uznać uzyskane wyniki jedynie za wstępne i orientacyjne w problematyce badań nad tożsamością sportową osób z niepełnosprawnością intelektualną.
Due to limitations resulting from the lack of division according to gender, the obtained results may be perceived only as initial and approximate findings in the field of athletic identity of individuals with intellectual disabilities. 


\section{Piśmiennictwo/References:}

4. Koszewska K. Program Edukacyjny Olimpiad Specjalnych Polska, Dołącz do nas, podręcznik dla nauczycieli szkół ponadpodstawowych. Warszawa: Biuro Narodowe Stowarzyszenia Olimpiady Specjalne Polska; 2010.

5. Wiliński W, Wieczorek M, Drzewakowska B. Osobowość sportowa zawodników Olimpiad Specjalnych - badania pilotażowe. Post Rehab 2014; 28(1): 37-45.

6. Schalock RL, Borthwick-Duffy SA., Bradley VJ, Buntinx WHE, Coulter DL, Craig EM, et al. Intellectuan disability: definition, classification and system of supports. Washington: AAIDD; 2010.

7. Bobińska K, Pietras T, Gałecki P. Niepełnosprawność intelektualna: etiopatogeneza, diagnoza, terapia. Wrocław: Continuo; 2012.

8. Erikson EH. Tożsamość a cykl życia. Kraków: Kantor Wydawniczy Zakamycze; 2004.

9. Tyszka A. Tożsamość kulturowa Regionu Kociewskiego 2000. Tożsamość kulturowa obszarów przygranicznych w dobie globalizacji. Pelplin: Bernardinum; 2006.

10. Kozielecki J. Psychologiczna teoria samowiedzy. Warszawa: Wydawnictwo PWN; 1986.

11. Tajfel H. Social psychology of intergroup relations. Annu rev psychol 1982; 33(1): 1-39.

12. Krzywy M. Pływanie osób z niepełnosprawnością intelektualną na przykładzie zawodników Olimpiad Specjalnych, Wrocław: Praca magisterska, Akademia Wychowania Fizycznego we Wrocławiu; 2013.

13. Benerfeind J, Tasiemski T, Wiśniowska M. Ocena osobowości sportowej osób niepełnosprawnych uprawiających siatkówkę na siedząco. Physio 2012; 20(1): 10-19.

14. Cedro P. Społeczna rola sportu. Rozpr Społ 2013; 7(2): 77-86.

15. Lesiuk A, Martyniuk K. Aktywizacja osób niepełnosprawnych intelektualnie poprzez Olimpiady Specjalne. In: Rutkowska E, Płaszewski M. editor. Aktywizacja osób z niepełnosprawnością, wybrane problemy medyczne i kultury fizycznej. Biała Podlaska: AWF Warszawa; 2014.

16. Tasiemski T, Brewer BW. Athletic Identity, Sport Participation and Psychological Adjustment In People With Spinal Cord Injury. Adapt Phys Activ Q Jul 2001; 28(3): 233-250.

17. Tasiemski T, Wilski M, Mędak K. An assessment of athletic identity in blind and ablebodied tandem cyclists. Hum Mov 2012; 13(2): 178-184.

18. Harada CM, Siperstein GN. The sport experience at athletes with intellectual disabilities: a national survey at Special Olympics athletes and their families. Adapt Phys Activ Q 2009; 26(1): 68-85. 